\title{
Quality of Citizen Reporting Tools at Municipal Level
}

\author{
Hana Kopackova ${ }^{1 *}$, Petra Libalova ${ }^{1}$ \\ ${ }^{1}$ Faculty of Economics and Administration, University of Pardubice, CZECH REPUBLIC
}

*Corresponding Author: hana.kopackova@upce.cz

Citation: Kopackova, H. and Libalova, P. (2019). Quality of Citizen Reporting Tools at Municipal Level. Journal of Information Systems Engineering \& Management, 4(3), em0092. https:/ /doi.org/10.29333/jisem/5891

Published: August 22, 2019

\begin{abstract}
Quality of life in cities is highly dependent on the state of public infrastructure. Maintenance of the infrastructure is managed by the local government that needs to be informed about issues on the infrastructure. Although the duty of maintenance staff is to check the state of the infrastructure, it is difficult to know about all the problems in the city. Therefore, citizens can take the initiative and participate by reporting any issue on public infrastructure. Today, citizens have many options on how to report such issues, due to modern communication technologies. Citizen reporting systems, which are a special type of participatory technology, deserve deeper research due to its novelty in the information system research. In this article, we introduce the study of 13 Czech regional capitals and their reporting systems. In this study, we evaluate the existence of different types of communication channels (phone, e-mail, electronic form, WebGis, and mobile application) and their quality based on four criteria (searchability, coverage of issues, visual geolocation, and display of sent reports). Moreover, the results of regional capitals will be compared with previous research on cities in these regions.
\end{abstract}

Keywords: citizen reporting, smart cities, non-emergency, e-participation

\section{INTRODUCTION}

Smart cities are the phenomena of the present days. These cities use technologies at the level of public administration not only to manage and execute state administration and self-government (smart governance) but also to involve them in the everyday life of the city's inhabitants. This direction of development is a reaction to two facts - the need to solve urbanization problems and the options given by the development of new technologies. Here, technology serves as a driving force to solve old problems in new ways, and as an innovation that brings new opportunities to enhance sustainable development (Caragliu et al., 2011; Mulligan and Olsson, 2013). Smart governance covers higher efficiency and effectiveness of city government, together with the focus on citizens' needs (eg. Dirks and Keeling, 2009; Kopackova, 2019; Nam and Pardo, 2011). Cities, to become smart, need to listen to their citizens; otherwise, they will spend their financial resources inefficiently on some IT gadgets. Moreover, citizens can perceive government initiatives as nontransparent if they are not listened (Michels and De Graaf, 2010).

The importance of citizen participation and engagement emphasizes many authors (eg. Ho and Coates, 2004; Nabatchi et al., 2017; Neshkova and Guo, 2012; Swindell and Kelly, 2000; Susanto et al., 2017) and organizations. For example, OECD (OECD handbook, 2001:60) reported: "engaging citizens in active participation in policy-making is the most advanced way of strengthening government-citizen relations. It means that the government acknowledges and supports citizens' own, autonomous role in the relationship". Michels and De Graaf (2010: 489) have studied the impact of citizen participation on local policymaking: "citizen involvement 
in policymaking makes people feel more responsible for public matters and increases public engagement". This statement is in line with higher citizens' needs defined by Kopackova (2019).

Citizen participation can take many forms; starting with the more passive form of evaluation of the contemporary situation realized by satisfaction surveys and continuing with a vast amount of participation tools as discussion forums, e-voting, e-petitioning, decision-making tools, etc. Each tool, which is useful in a different situation, brings its pros and cons but what they have in common is the activity of citizens; their willingness to participate. Linders (2012: 447) explains the difference in roles of government and citizens within citizen coproduction: "government holds primary responsibility, but citizens influence direction and outcomes, improve the government's situational awareness, and may even belp execute government services on a day-to-day basis".

The citizen reporting tool is a participatory technology that allows citizens to report issues on public infrastructure that are not urgent. This can be an illegal dump, unfunctional lighting, broken benches or play elements on the playground, potholes on the road or in the sidewalk, uncut grass, untidy snow, etc. Generally, these problems lower the quality of life in the city, but they are not life-threatening. Citizens in all municipalities have the opportunity to express their dissatisfaction, but the possibilities of the communication channels differ. Incidents that are life-threatening or such incidents with a danger of delay need a fast response; therefore, reporters should use some fast reporting system - hotline. On the other hand, non-urgent incidents can be reported via diverse communication channels, which emerged with the development of digital technologies. The emergence of such technologies motivated the research published in this article.

This article is an extended version of the previously published paper on the IEEE conference - CISTI (Kopackova and Libalova, 2019). The article is organized as follows. The following chapter clarifies the origins of citizen reporting concept and relationship to related concepts. Moreover, it shows contemporary trends in the research. Next chapter introduces different types of reporting channels that can be used by city governments. Chapter 4 describes the methodology of the research, whereas chapter 5 introduces the results of the evaluation of Czech regional capitals according to the use of citizen reporting systems. Chapter 6 summarizes these results and discuss future research options.

\section{CITIZEN REPORTING CONCEPT}

Large American cities have been dealing with issues on public infrastructure for a long time. Already in 1996, the first emergency hotline 311 in Baltimore was introduced, in addition to the 911 line (O’Byrne, 2015). The original idea of establishing line 311 was to relieve the hotline 911, which was not only called by people in danger of life but also blocked by problems that were not urgent. Another reason was the fragmentation of information, so in the event of a problem, people had to find out which organization or department was dealing with the problem. Therefore, a single hotline was established. Over time, data from line 311 has become a good source of knowledge about the state of the city, the reactivity of local government and the needs of citizens. Moreover, this system has raised citizens' participation to an unexpected level. Offenhuber (2014: 5) summarizes the view on 311 systems: “...311 systems imply a two-way contract between the government and the citizens. The city commits to responding to citizen requests in a timely manner and offers a mechanism for the citizens to track requests. In return, the citizens contribute data that again is made publicly accessible". The number 311 has become a symbol of reporting issues on public infrastructure and most research literature from the US environment use the name 311 systems for these tools (including web and mobile).

Although the citizen reporting concept is not new, there is no research article clarifying the whole concept. What is missing is clear terminology, which complicates the research and implementation of new approaches and methods. At first, the title of such technology needs to be defined. Clarification of the citizen reporting title, based on the systematic literature review of 54 papers, was published in (Kopackova et al., 2019). They proposed the abbreviation CRIsPI, which stands for Citizen Reporting of Issues on Public Infrastructure. CRIsPI technology can be classified as a system if there are more channels on how to report the issue or a tool when speaking about one particular channel for reporting.

Another step in clarification of the CRIsPI concept is to explore the relationships to other concepts that appear in articles about citizen reporting. Table 1 shows the most frequent concepts with the explanation of the relationship to CRIsPI and literature sources. All described concepts except for 311 systems are conceptually broader than CRIsPI itself. On the contrary, 311 systems concept is narrower, not conceptually but spatially. 311 hotline is used only in the US, the rest of the world do not use it, and therefore, probably, researchers would not search for the literature with this concept. The widest concepts in the table are citizen relationship management and e-participation, which both focuses on a positive relationship with citizens but they are not limited to issues of public infrastructure. PPGIS concept concerns a special type of technology, geographic information systems that simplify the process of reporting. However, only some communication channels for citizen reporting use this tool. Moreover, PPGIS is not focused only on urban issues. Three other concepts consider the activity of citizens 
Table 1. Related concepts to CRIsPI

\begin{tabular}{|c|c|c|}
\hline Related concepts & Explanation of the relationship & Sources \\
\hline $\begin{array}{l}\text { Citizen relationship } \\
\text { management }\end{array}$ & $\begin{array}{l}\text { Comes from customer relationship management, has broader } \\
\text { meaning, covering all relationships with citizens not only } \\
\text { public infrastructure reporting. }\end{array}$ & $\begin{array}{l}\text { (e.g. Hartmann et al., 2017; Crawford and } \\
\text { Walters, 2013; Kannabiran et al. 2004) }\end{array}$ \\
\hline Urban sensing & $\begin{array}{l}\text { Gathering of data about urban environment, sensors does } \\
\text { not have to be people. }\end{array}$ & $\begin{array}{l}\text { (e.g. Campbell et al., 2006; Dutta et al., 2009; } \\
\text { Winkler, et al., 2012a; Winkler, et al., 2012b) }\end{array}$ \\
\hline $\begin{array}{l}\text { Live sensors, } \\
\text { citizen sensing }\end{array}$ & $\begin{array}{l}\text { People act as sensors gathering data. Data does not have to } \\
\text { be from urban environment. }\end{array}$ & $\begin{array}{l}\text { (e.g. Boulos et al., 2011; Gabrys, 2014; Borges } \\
\text { et al., 2016; Sheth, 2009)) }\end{array}$ \\
\hline 311 systems & $\begin{array}{l}\text { Correct scope of the concept, well known in the US context, } \\
\text { not worldwide. }\end{array}$ & $\begin{array}{l}\text { (e.g. Clark and Rokakis, 2014; Clark and } \\
\text { Brudney, 2017; Hartmann et al., 2017; Lu and } \\
\text { Johnson, 2016; Nam and Pardo, 2014; } \\
\text { Offenhuber, 2014) }\end{array}$ \\
\hline $\begin{array}{l}\text { PPGIS (public } \\
\text { participation geographic } \\
\text { information system) }\end{array}$ & $\begin{array}{l}\text { Covers all information systems designed for the public to } \\
\text { gather spatial data. It is not necessarily used by local } \\
\text { government and it does not have to concern public } \\
\text { infrastructure. }\end{array}$ & $\begin{array}{l}\text { (e.g. Floreddu and Cabiddu, 2012; Thompson, } \\
\text { 2016; Ramasubramanian, 2016; Ganapati, } \\
\text { 2011) }\end{array}$ \\
\hline Citizen sourcing & $\begin{array}{l}\text { Comes from crowdsourcing where crowd form citizens. The } \\
\text { purpose of the formation of the crowd is to take some action } \\
\text { in public interest. }\end{array}$ & $\begin{array}{l}\text { (e.g. Torres, 2007; Nam, 2012; You et al., } \\
\text { 2016; Motta et al., 2014) }\end{array}$ \\
\hline $\begin{array}{l}\text { Participation } \\
\text { application, } \\
\text { e-participation }\end{array}$ & $\begin{array}{l}\text { Broad concept covering all forms of civic engagement, } \\
\text { enhanced by the e-government } 2.0 \text {. }\end{array}$ & $\begin{array}{l}\text { (e.g. Linders, 2012; Atzmanstorfer and } \\
\text { Blaschke, 2013; Aitken, 2014) }\end{array}$ \\
\hline
\end{tabular}

\section{Solving capacity of maintenance team}

Setting of processes - contact center ensures distribution of reports

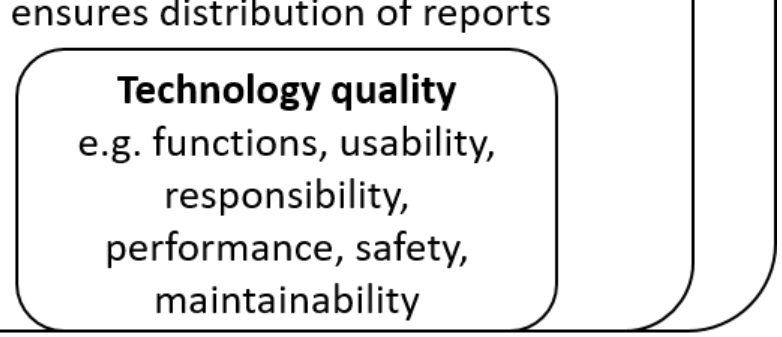

Figure 1. Necessary components of CRIsPI success

(gathering of data). Citizen sensing and urban sensing emphasize that citizens act as sensors whereas citizen sourcing accentuates that local governments can exploit their citizens as an additional workforce.

Another topic in clarifying CRIsPI concept is the success of citizen reporting. What are the antecedents of the success of CRIsPI technology? At first, we must emphasize that the success of any CRIsPI technology is possible only if both sides; citizens and local government accept this technology. That is why one direction of the research in this field concentrates on the acceptance whether on the side of citizens or local government (Schmidthuber et al., 2017; Susanto et al., 2017; Winkler et al, 2012a). Moreover, on the side of citizens is often studied the motivation to use such tools (Abu-Tay et al., 2018; O’Brien et al., 2017; Offenhuber, 2014). The adoption of CRIsPI tool is based on expectations that both sides have but their willingness to continue using this tool is based on their experience. Contemporary research literature revealed three main components that influence satisfaction with reporting technology (see Figure 1). The core requirement is the quality of technology. Citizens will not use technology with poor performance, difficult to operate, with safety and privacy threats. Much of the research is therefore focused on the technology itself (Consoli et al., 2015; De Filippi et al., 2016; You et al., 2016). However, technology itself cannot ensure the satisfaction of users. The technology must be implemented into an organizational environment with adjustment of processes. Operating personnel must be qualified and convinced of the importance of this service. The workflow must be defined to distribute the reports without additional interference of citizens (Consoli et al., 2015). Finally yet importantly, sufficient solving capacity of the maintenance team is necessary. Citizens will be satisfied only when the problem is resolved, the answer from the contact center is the first feedback but it is not enough. Research in this field also covers topics about efficient communication with maintenance team (Crawford and Walters, 2013). 


\section{COMMUNICATION CHANNELS FOR CITIZEN REPORTING}

Each local government chooses a specific combination of reporting channels to form its CRIsPI system. First, we start with channels invoked as the initiative of local government.

Phone call - the original way of gathering non-emergency reports dates back to the last century. Approaches to this media differ in each municipality. Some of them use call center with unified three-digit number 311, some have a different number, and others use more than one number for non-emergency calls divided by fault type (road maintenance, damage to municipal property, disservice of utilities, greenery damage, etc.).

E-mail - brought first online reporting possibility. The advantage of the e-mail is that it is asynchronous communication and the problem is directed to the right person. However, the e-mail is unstructured without length limitation, which means that some reports can be lengthy and incomprehensible.

Electronic form - have the same advantage of asynchronous communication; moreover, it brings a higher level of structure. The specific structure of the form depends on the needs of local government.

GIS-based web solution - geographic information systems (GIS) enrich citizen reporting on the spatial component. While using a phone, e-mail or electronic form citizens must describe the place of the incident by address or some textual description, GIS allows for selection of the place in the map (DeMeritt and Writer, 2011). The use of GIS gives municipalities' great deal of options. The least expensive solution is the use of mashup of an existing map (eg. Google map) and electronic form. Local governments can use the existing form and just improve its features by adding the clickable map. The second option is the use of existing geoportal that the municipality uses and add the component for sending the reports. This solution has the advantage for users of using the known environment. The most expensive GIS solution is specialized geoportal.

Mobile application - the wave of smartphones brought new possibilities even for citizen reporting. Mobile applications for citizen reporting became popular mostly as civic apps but the local government also initiate the creation of mobile CRIsPI solution. Recently there are two main streams of mobile solutions. First is a specialized application for the non-emergency reporting in the competence of the municipality. Second can be called municipal mobile application that covers a wide range of features (eg. traffic info, tourist info, cultural events, parking) one of which is reporting of issues on public infrastructure.

Social networks - gives citizens the possibility to use a familiar environment, which they use in their personal life, on the other hand, processing of this information is more demanding due to unstructured nature of the information.

Local governments are not limited to channels invoked by them. Citizens often take the initiative and create so-called civic apps. Usually, such universal applications are not location-specific (e.g. SeeClickFix, FixMyStreet, ImproveMyCity) and bring the possibility to report non-emergency incidents both, via the web interface and over the mobile. Universal applications can be very helpful for municipalities without their web or mobile channel. Mostly these applications offer to send report e-mails to predefined persons as the free service. Customization and integration into municipalities CRM is a paid service. In the Czech Republic, there is one application originating from a civic app named ZmapujTo. This application can be used by citizens of any registered municipality in the Czech Republic. Since 2012, registration and administration of reports were free for all municipalities but now, the policy is changing, and the service is charged. The environment of this application is shown in Figure 2.

Municipalities with their web and mobile channels do not always perceive the involvement of these universal applications as advantageous. They invested quite a lot of money into their solution and do not want it to be wasted. Moreover, some people would use their solution, and some would use the universal application, which forces responsible persons to monitor more channels. That is why some officials are skeptical, feeling that "(it) simply duplicated existing channels, especially the local council website" (King and Brown, 2007). 


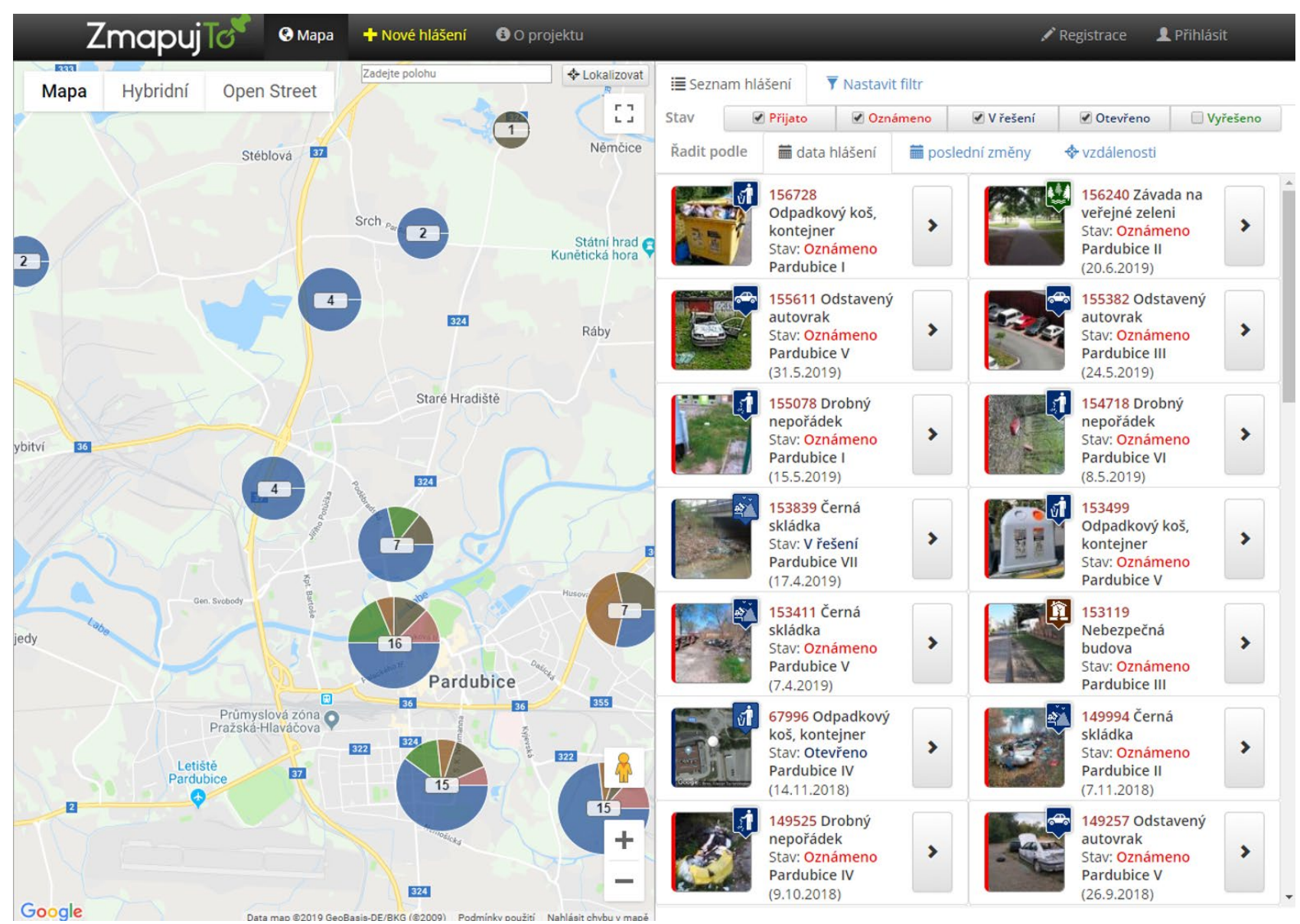

Figure 2. Civic application ZmapujTo

\section{METHODOLOGY}

A case study in this paper evaluates the offering of citizen reporting tools in thirteen regional capitals in the Czech Republic. The evaluation was held in July 2018 and it is part of a longitudinal study about CRIsPI systems in the Czech Republic. The process of the evaluation consisted of four phases. At first, we searched Google with a phrase containing "name of the city + reporting of issues". In the second phase, we searched for the city webpage, where we were looking for a reference on how to report the problem. These two phases imitated the search of an ordinary citizen who wants to report some issue on public infrastructure. Examples of incidents were further specified as damaged benches, mess, broken pavement, uncut grass, landfills, potholes, broken lights, or abandoned vehicle. If there were no option to report the issue, then the process would stop. Communication channels were categorized into five categories (phone, e-mail, electronic form, WebGis, and mobile application), with the fact that the municipality may have one or more different channels. In the third phase were these channels evaluated according to four criteria:

a) searchability - how difficult was to find particular channels (LOW/MEDIUM/HIGH);

b) coverage of issues - eight types of issues were defined (2-LOW/5-MEDIUM/8-HIGH);

c) visual geolocation - inserting an incident location by clicking on the map (YES/NO);

d) display of sent reports - if the user sees reports sent by other users (NO/LIST/MAP).

The last phase comprised the comparison of results of this research and previously published data in (Kopackova et al., 2019).

\section{RESULTS OF THE CASE STUDY}

Cities in the Czech Republic never used any unified phone number for non-emergencies, such as 311 hotline in the US. Each city has its number and very frequently, there is not only one. Especially big cities as Prague or Brno make it difficult for their citizens to report some issue because there are different phone numbers for each service and moreover each part of the city has their providers. The division of the cities made it complicated also 
Table 2. Summary of communication channels for citizen reporting (Kopackova and Libalova, 2019)

\begin{tabular}{|c|c|c|c|c|c|}
\hline City name & Inhab & Email & El. form & WebGIS & MA \\
\hline Brno & 377973 & $\mathrm{x}$ & $\mathrm{x}$ & $\mathrm{x}$ & $\mathrm{x}$ \\
\hline České Budějovice & 93470 & $\mathrm{x}$ & $\mathrm{x}$ & $\mathrm{x}$ & $\mathrm{x}$ \\
\hline Hradec Králové & 92929 & & $\mathrm{x}$ & & $\mathrm{x}$ \\
\hline Jihlava & 50559 & & & $\mathrm{x}$ & \\
\hline Karlovy Vary & 49046 & $\mathrm{x}$ & $\mathrm{x}$ & & $\mathrm{x}$ \\
\hline Liberec & 103853 & & $\mathrm{x}$ & $\mathrm{x}$ & \\
\hline Olomouc & 100378 & & $\mathrm{x}$ & & \\
\hline Ostrava & 291634 & $\mathrm{x}$ & $\mathrm{x}$ & & \\
\hline Pardubice & 90044 & & $\mathrm{x}$ & & $\mathrm{x}$ \\
\hline Plzeň & 170548 & & & $\mathrm{x}$ & $\mathrm{x}$ \\
\hline Praha & 1280508 & $\mathrm{x}$ & $\mathrm{x}$ & $\mathrm{x}$ & $\mathrm{x}$ \\
\hline Ústí nad Labem & 92984 & $\mathrm{x}$ & & & \\
\hline Zlín & 75117 & $\mathrm{x}$ & $\mathrm{x}$ & & $\mathrm{x}$ \\
\hline
\end{tabular}

for our evaluation. For example, Prague is divided into 57 self-governing parts and Brno in 29. It was not possible to evaluate each part separately, therefore, we decided to take into consideration only tools with the coverage of the whole territory of the city. This fact is important for the explanation of quite a bad result of these two biggest cities. If we searched even city self-governing parts, we could present very good solutions for example from PraguePetrovice, Prague 2, Prague-Libuš and so on. However, fragmentation of available solutions requires citizens to know exactly in what part of the city they found the problem.

13 evaluated regional capitals differ in their size from 49000 to 1200000 . However, all of them are big enough to take advantage of specialized communication channels for reporting. All cities have at least one phone number dedicated to reporting issues on public infrastructure, so we evaluated other channels (e-mail, electronic form, WebGis, mobile application). Results of the evaluation are depicted in Table 2. From this summary, it is obvious that most cities offer their citizens more than one option for communication with city officials. Nevertheless, this evaluation is quantitative and does not refer to the quality of the offered solutions. That is why we set four qualitative evaluation criteria (searchability, coverage of issues, visual geolocation, and display of sent reports). The evaluation was city-centered, not solution centered, which means that if the city had more communication channels, the evaluation was based on the best one. According to results, cities were classified into three categories. The first category included cities with the highest quality of CRIsPI systems. The second category is the widest and contains cities having some minor problems. The last category contains cities with the lowest quality of available communication channels.

\section{Cities with the Highest Score - České Budějovice, Plzeň, Liberec}

All three cities in this category offer their citizens channels that are easy to find, cover all spectra of issues, use visual geolocation, and show sent reports in the form of a map. Figures 3-5 show sent reports for selected cities. Although the results of the evaluation are the same for these cities, their technical solutions highly differ.

The city of Plzeň use their solution, which is both; WebGIS based (Plznito) and mobile (Plzeň občan). The mobile application put together information from local government and the reporting module for citizens as the municipal application. Both ways, mobile app, and WebGIS can be used to see the status of reported incidents or to report a new one. Both channels have a similar user interface, which makes the use of it much easier.

Ceské Budějovice uses DejTip application, which is a mobile application operated by the third party, related to a wider area than the city, and specialized in reporting. This city uses also their electronic form and WebGIS solution, which is based on DejTip application. The number of communication channels for citizens is the highest; however, the usability would be higher if the displayed reports would show also the description of the issue, not only the category and the address.

The city of Liberec uses geoportal Marushka, which they use as a GIS solution for the evidence of municipal property. Description of the issue is displayed after clicking on the object in the map. However, it is not possible to filter issues according to date or issue type, as it is possible in Plzeň and České Budějovice. 


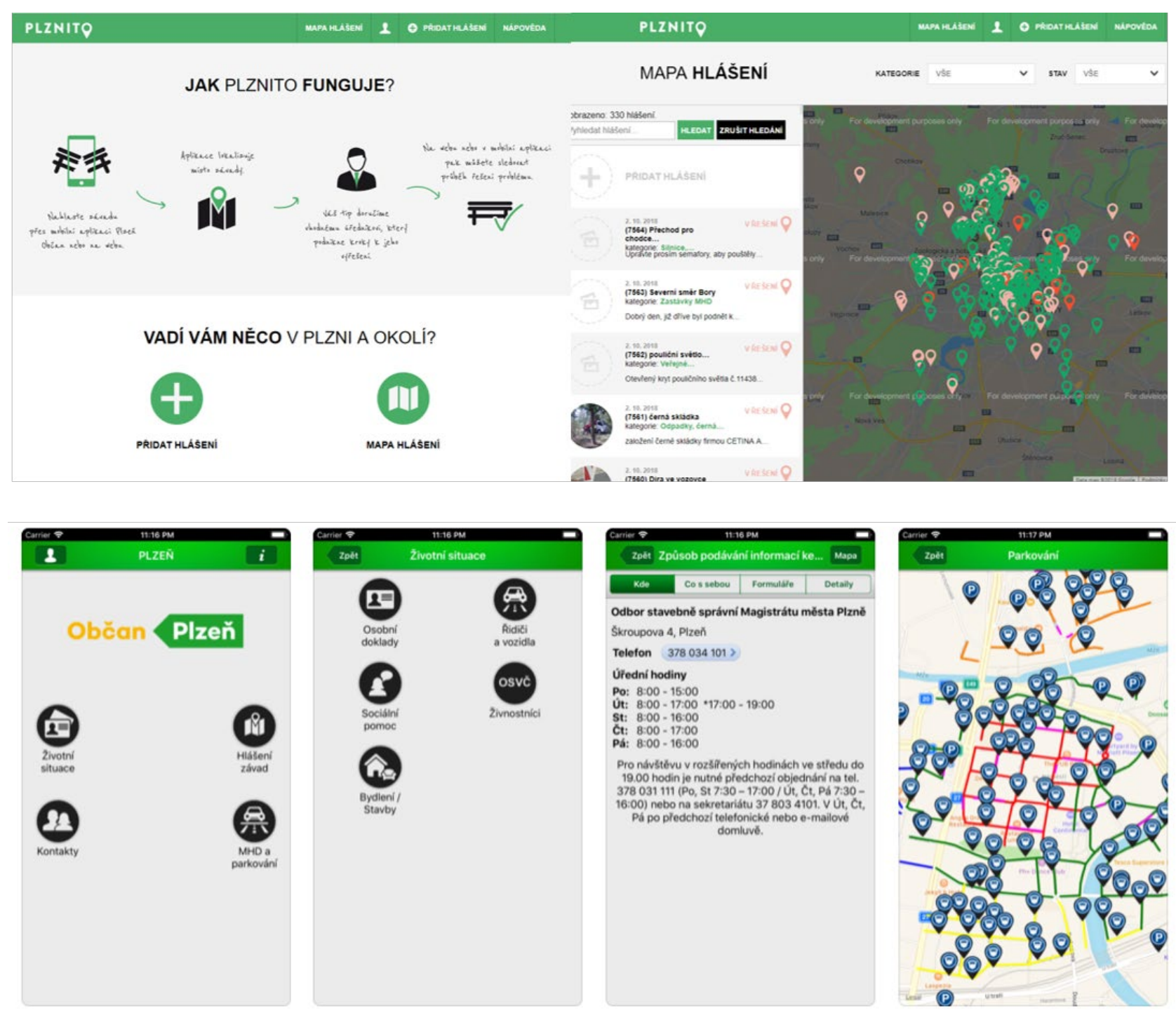

Figure 3. Two channels for citizen reporting in Plzeň (webGIS and mobile app)
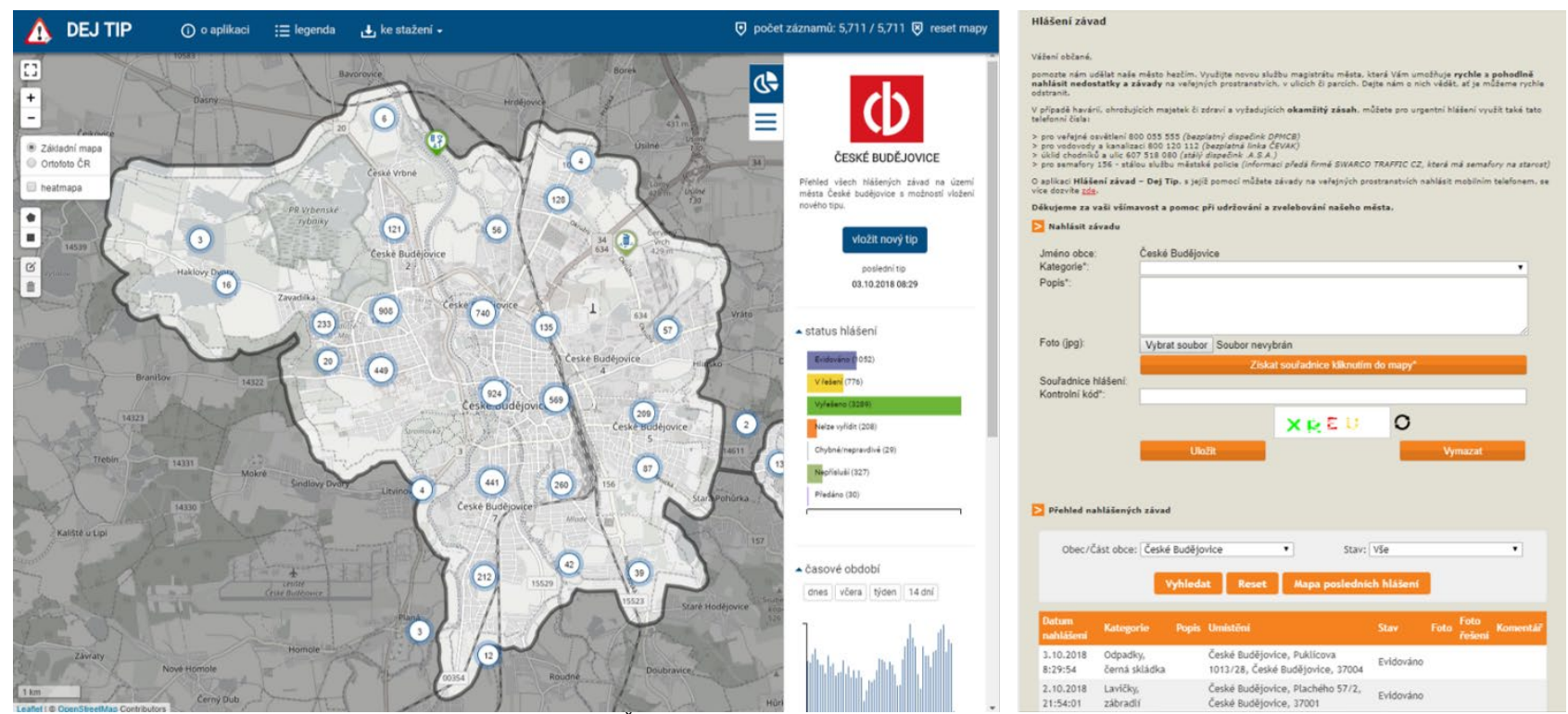

Figure 4. Two communication channels in Ceské Budějovice (webGIS and electronic form) 


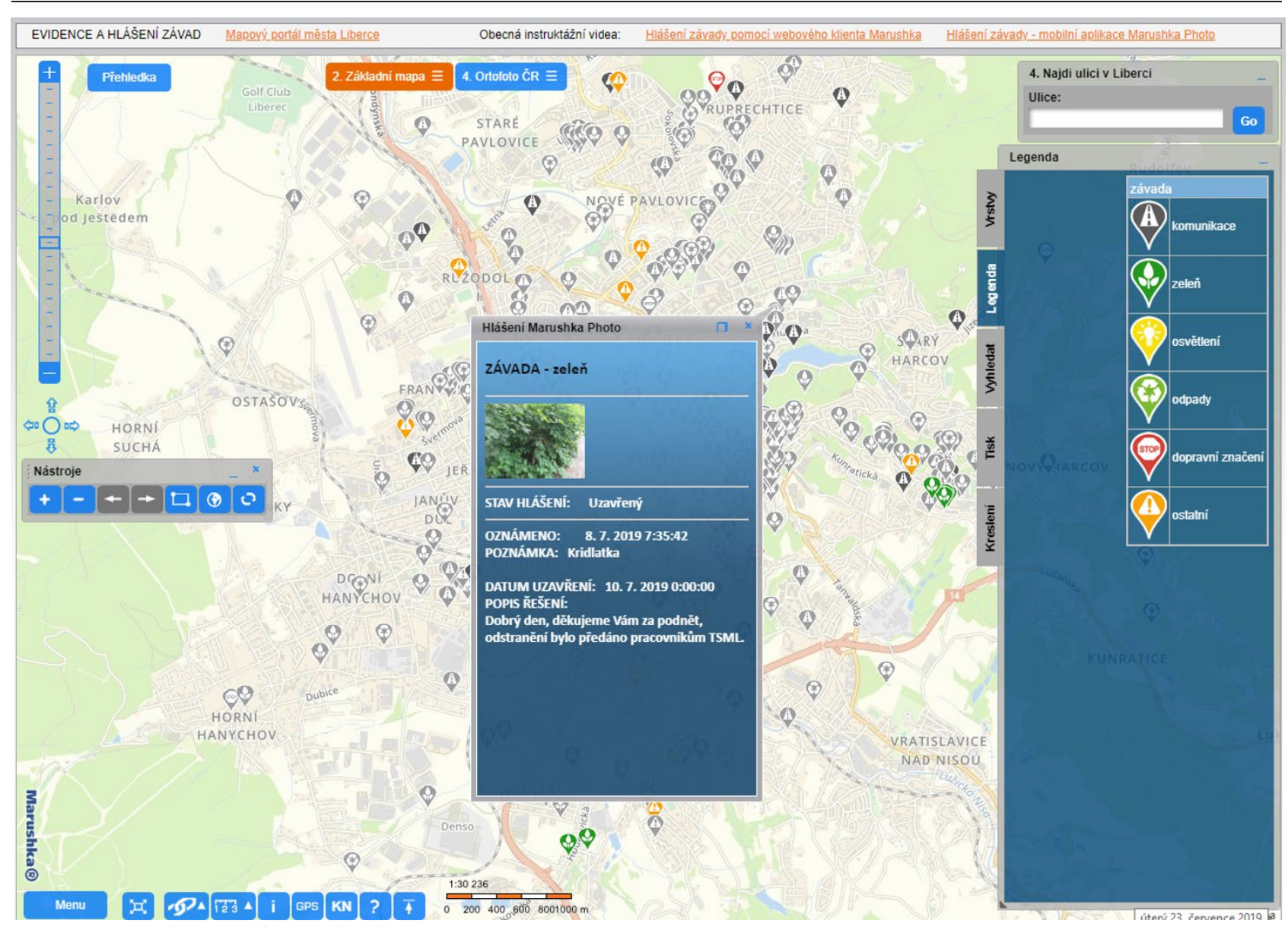

Figure 5. WebGIS solution in Liberec

\section{Cities with Minor Quality Issues - Ostrava, Pardubice, Prague, Jihlava, Brno}

Five cities did not comply with one quality criterion. City of Ostrava and Pardubice display sent reports only in the form of the list. Prague and Jihlava do not display sent reports at all. Brno has lower coverage of issues (roads, street lights, and suburban forests).

\section{Cities with more than One Quality Issue - Karlovy Vary, Hradec Králové, Olomouc, Ústí nad Labem, Zlín}

Five cities have more quality issues than one. At first, no city in this category uses visual geolocation. Another challenging issue was the display of sent reports. Karlovy Vary presents them in the form of the list, other cities do not display them at all (Hradec Králové, Olomouc, Ústí nad Labem, Zlín). City of Hradec Králové have also very low coverage of issues (streetlights). The worst score obtained the city of Ústí nad Labem, which offer their citizens only e-mail for reporting non-emergency issues and it was very difficult to find.

\section{Comparison of Quality Evaluation of Regional Capitals with the Use of CRIsPI Tools in Regions}

Evaluation of regional capitals, published in this article is a part of a longitudinal study about CRIsPI systems in the Czech Republic. Due to this fact, we can compare the penetration of CRIsPI tools in cities within the region with its capital. The assumption is that capitals should be leaders, which spread knowledge through the region if they use the quality system. Evaluated cities in regions were selected based on their size, only cities with more than 1000 inhabitants were evaluated. In total, there were 1444 municipalities. Results for regions were published in (Kopackova et al., 2019).

There is one thing that makes the comparison complicated. In the Czech Republic, there are 14 regions but only 13 regional capitals because Prague is the region itself (Praha) but it is also capital for Středočeský region (see Figure 6). In the comparison presented here, Prague will be evaluated only as of the capital of Středočeský region. Results can be found in Table 3. A very surprising fact is the ranking of Plzeň and Plzeňský region. Whereas Plzeň as the city scored the best and their solution is on a very high level, the whole region is at the bottom of the ladder. Only $13.2 \%$ of cities have any communication channel dedicated to reporting of issues on public infrastructure. If we compare the area and the average distance from the regional capital, it is at the medium level with quite a low number of cities. There is no objective reason for such a different scoring except for poor communication and 


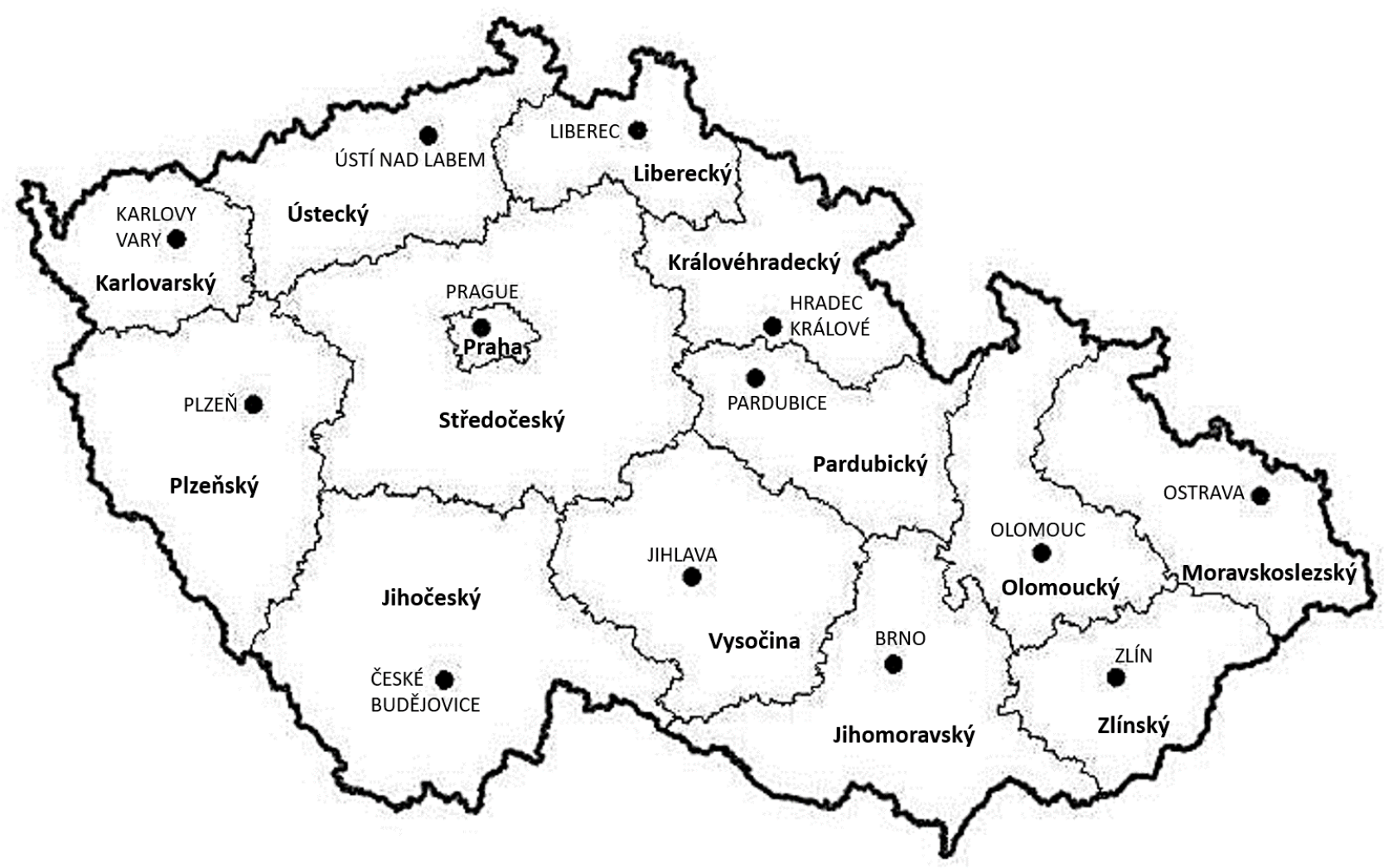

Figure 6. Regions and regional capitals of the Czech Republic

Table 3. Ranking of regions in comparison to the ranking of cities

\begin{tabular}{|c|c|c|c|c|c|c|c|}
\hline $\begin{array}{l}\text { Regions } \\
\text { ranking }\end{array}$ & Region & $\begin{array}{c}\text { Area } \\
\left(\mathrm{km}^{2}\right)\end{array}$ & No. of cities & $\begin{array}{l}\text { Avg. dist. } \\
\text { from capital }\end{array}$ & $\begin{array}{l}\text { Penetration of } \\
\text { CRIsPI tools }\end{array}$ & $\begin{array}{c}\text { Cities } \\
\text { ranking }\end{array}$ & Cities \\
\hline 1 & Liberecký - Liberec & 3163,4 & 60 & 23360,29 & $36,7 \%$ & 1 & Plzeň \\
\hline 2 & Karlovarský - Karlovy Vary & 3314,3 & 42 & 22389,6 & $31,0 \%$ & 2 & České Budějovice \\
\hline 3 & Jihomoravský - Brno & 7195,1 & 190 & 33460,85 & $30,5 \%$ & 3 & Liberec \\
\hline 4 & Moravskoslezský - Ostrava & 5427,6 & 155 & 27585,72 & $27,7 \%$ & $4-8$ & Ostrava \\
\hline 5 & $\begin{array}{l}\text { Královéhradecký - Hradec } \\
\text { Králové }\end{array}$ & 4759 & 77 & 32168,98 & $26,0 \%$ & $4-8$ & Pardubice \\
\hline 6 & Zlínský - Zlín & 3963 & 108 & 25614,93 & $25,9 \%$ & $4-8$ & Prague \\
\hline 7 & Vysočina - Jihlava & 6795,6 & 67 & 30563,11 & $23,9 \%$ & $4-8$ & Jihlava \\
\hline 8 & Jihočeský - České Budějovice & 10058 & 102 & 35437,54 & $23,5 \%$ & $4-8$ & Brno \\
\hline 9 & Pardubický - Pardubice & 4518,9 & 81 & 36359,32 & $23,5 \%$ & $9-13$ & Karlovy Vary \\
\hline 10 & Ústecký - Ústí nad Labem & 5334,6 & 95 & 32226,88 & $23,2 \%$ & $9-13$ & Zlín \\
\hline 11 & Olomoucký - Olomouc & 5266,9 & 120 & 30002,78 & 5266,9 & $9-13$ & Olomouc \\
\hline 12 & Stř̌edočeský - Prague & 11016,1 & 255 & 34007,91 & $21,6 \%$ & $9-13$ & Hradec Králové \\
\hline 13 & Plzeňský - Plzeň & 7561 & 91 & 30242,34 & $13,2 \%$ & $9-13$ & Ústí nad Labem \\
\hline
\end{tabular}

low level of knowledge transfer. On the contrary, Liberec scored high at the level of the city and even as the region. Liberecký region is the smallest in the Czech Republic, with the second smallest number of cities and the average distance from the capital. This territorial compactness can be one of the explanatory factors.

\section{CONCLUSIONS}

This article brought deeper understanding of citizen reporting concept by exploring related concepts and current research trends in this field. It also summarized possible communication channels. The case study brought the evaluation of the use and quality of CRIsPI systems in 13 Czech regional capitals. The results showed that cities offer their citizens various channels to report non-emergencies. Against the expectations, we found out that those cities do not use same or similar solutions. Although the electronic form is the most popular, mobile applications and WebGIS solutions are also popular among evaluated cities. Quality of offered solutions differ but we are able to find three cities as the examples of the good practice; Plzeň, České Budějovice, and Liberec. These cities can be seen as real smart cities listening to the voice of their citizens. Last part of the research revealed that 
there is no tight cooperation between regional capitals and cities in the region. The data showed that the penetration of CRIsPI tools in the region mostly do not correspond to the quality of capitals solutions.

As the limitation of the study, we can mention the focus of the study only on the supply side at the local government level. Future research should consider the level of use by citizens, their satisfaction and the responsiveness of local government. However, this research will be possible only if cities publish sent reports with their status.

\section{ACKNOWLEDGEMENT}

The paper has been completed with the kind support of SGS_2019_17 project, Students grant competition of the University of Pardubice.

\section{REFERENCES}

Abu-Tayeh, G., Neumann, O. and Stuermer, M. (2018). Exploring the Motives of Citizen Reporting Engagement: Self-Concern and Other-Orientation. Business \& Information Systems Engineering, 60(3), 215-226. https://doi.org/10.1007/s12599-018-0530-8

Aitken, M. (2014). E-Planning and Public Participation: Addressing or aggravating the challenges of public participation in planning? International Journal of E-Planning Research (IJEPR), 3(2), 38-53. https://doi.org/10.4018/ijepr.2014040103

Atzmanstorfer, K. and Blaschke, T. (2013). The geospatial web: A tool to support the empowerment of citizens through Eparticipation? In Citizen e-Participation in urban governance: Crowdsourcing and collaborative creativity, IGI Global, 144-171. https://doi.org/10.4018/978-1-4666-4169-3.ch009

Borges, J., Budde, M., Peters, O., Riedel, T. and Beigl, M. (2016). Towards two-tier citizen sensing. In 2016 IEEE International Smart Cities Conference (ISC2), 1-4. https://doi.org/10.1109/ISC2.2016.7580771

Boulos, M. N. K., Resch, B., Crowley, D. N., Breslin, J. G., Sohn, G., Burtner, R., ... and Chuang, K. Y. S. (2011). Crowdsourcing, citizen sensing and sensor web technologies for public and environmental health surveillance and crisis management: trends, OGC standards and application examples. International journal of health geographics, 10(1), 67. https://doi.org/10.1186/1476-072X-10-67

Campbell, A. T., Eisenman, S. B., Lane, N. D., Miluzzo, E. and Peterson, R. A. (2006). People-centric urban sensing. In Proceedings of the 2nd annual international workshop on Wireless internet, 18-26. https://doi.org/10.1145/1234161.1234179

Caragliu, A., Del Bo, C., and Nijkamp, P. (2011). Smart cities in Europe. Journal of urban technology, 18(2), 65-82. https://doi.org/10.1080/10630732.2011.601117

Citizens as Partners. OECD handbook on information, consultation and public participation in policy-making. (2001). [Online]. Available at: https://www.internationalbudget.org/wp-content/uploads/Citizens-asPartners-OECD-Handbook.pdf (Accessed 10 March 2019)

Clark, B. Y. and Brudney, J. (2017). Too Much of a Good Thing? Frequent Flyers and the Implications for the Coproduction of Public Service Delivery. SSRN Electronic Journal. https://doi.org/10.2139/ssrn.2942269

Clark, B. Y. and Rokakis, M. (2014). Do 311 Systems Shape Citizen Satisfaction with Local Government? SSRN Electronic Journal, 2491034. https:// doi.org/10.2139/ssrn.2491034

Consoli, S., Recupero, D. R., Mongiovi, M., Presutti, V., Cataldi, G. and Patatu, W. (2015). An Urban Fault Reporting and Management Platform for Smart Cities. Assoc Computing Macbinery, 535-540. https:// doi.org/10.1145/2740908.2743910

Crawford, S. P. and Walters D. (2013). Citizen-Centered Governance: The Mayor's Office of New Urban Mechanics and the Evolution of CRM in Boston. SSRN Electronic Journal. https://doi.org/10.2139/ssrn.2307158

De Filippi, F., Coscia, C., Boella, G., Antonini, A., Calafiore, A., Cantini, A. ... and Schifanella, C. (2016). MiraMap: A We-Government Tool for Smart Peripheries in Smart Cities. IEEE Access, 4, 3824-3843. https://doi.org/10.1109/ACCESS.2016.2548558

DeMeritt, M. and Writer, E. (2011). Simplifying citizen reporting. ArcUser, Magazine for ESRI Software User, 14(1), 26-27.

Dirks, S. and Keeling, M. (2009). A vision of smarter cities: How cities can lead the way into a prosperous and sustainable future. Somers, NY: IBM Global Business Services

Dutta, P., Aoki, P. M., Kumar, N., Mainwaring, A., Myers, C., Willett, W. and Woodruff, A. (2009). Common sense: participatory urban sensing using a network of handheld air quality monitors. In Proceedings of the 7 th $A C M$ conference on embedded networked sensor systems, 349-350. https:// doi.org/10.1145/1644038.1644095 
Floreddu, P. B. and Cabiddu, F. (2012). Public decisions and citizen satisfaction: the potential role of public participation geographic information systems. International Journal of Electronic Commerce Studies, 3(1), $121-134$.

Gabrys, J. (2014). Programming environments: environmentality and citizen sensing in the smart city. Environment and Planning D: Society and Space, 32(1), 30-48. https://doi.org/10.1068/d16812

Ganapati, S. (2011). Uses of Public Participation Geographic Information Systems Applications in E-Government. Public Administration Review, 71(3), 425-434. https://doi.org/10.1111/j.1540-6210.2011.02226.x

Hartmann, S., Mainka, A. and Stock, W.G. (2017). Citizen relationship management in local governments: The potential of 311 for public service delivery. In Beyond Bureaucracy, Springer, $337-353$. https://doi.org/10.1007/978-3-319-54142-6_18

Ho, A. and Coates, P. (2004). Citizen-initiated performance assessment: The initial Iowa experience. Public Performance \& Management Review, 27(3), 29-50.

Kannabiran, G. M. J. X., Xavier, M. J. and Anantharaaj, A. (2004). Enabling e-governance through citizen relationship management-concept, model and applications. Journal of Services Research, 4(2).

King, S. F. and Brown, P. (2007). Fix my street or else: using the internet to voice local public service concerns. In Proceedings of the 1st international conference on Theory and practice of electronic governance, ACM, PP. 72-80. https://doi.org/10.1145/1328057.1328076

Kopackova, H. (2019). Reflexion of citizens' needs in city strategies: The case study of selected cities of Visegrad group countries. Cities, 84, 159-171. https://doi.org/10.1016/j.cities.2018.08.004

Kopackova, H. and Libalova, P. (2019). Citizen reporting as the form of e-participation in smart cities. In 2019 14th Iberian Conference on Information Systems and Technologies (CISTI), pp. 1-6, IEEE. https://doi.org/10.23919/CISTI.2019.8760931

Kopackova, H., Komarkova, J. and Jech, J. (2019). Technology helping citizens to express their needs and improve their neighborhood. In IEEE Information and Digital Technologies (IDT), pp. 225-231.

Linders, D. (2012). From e-government to we-government: Defining a typology for citizen coproduction in the age of social media. Government Information Quarterly, 29(4), 446-454. https://doi.org/10.1016/j.giq.2012.06.003

Lu, Q. and Johnson, P.A. (2016). Characterizing New Channels of Communication: A Case Study of Municipal 311 Requests in Edmonton, Canada. URBAN PLANNING, $1(2), \quad 18-31$. https://doi.org/10.17645/up.v1i2.621

Michels, A. and De Graaf, L. (2010). Examining citizen participation: Local participatory policy making and democracy. Local Government Studies, 36(4), 477-491. https:/ / doi.org/10.1080/03003930.2010.494101

Motta, G., You, L., Sacco, D. and Ma, T. (2014). City feed: A crowdsourcing system for city governance. In 2014 IEEE 8th international symposium on service oriented system engineering, pp. 439-445. https://doi.org/10.1109/SOSE.2014.64

Mulligan, C. E. and Olsson, M. (2013). Architectural implications of smart city business models: An evolutionary perspective. IEEE Communications Magazine, 51, 80-85. https:// doi.org/10.1109/MCOM.2013.6525599

Nabatchi, T., Sancino, A. and Sicilia, M. (2017). Varieties of participation in public services: The who, when, and what of coproduction. Public Administration Review, 77(5), 766-776. https://doi.org/10.1111/puar.12765

Nam, T. (2012). Suggesting frameworks of citizen-sourcing via Government 2.0. Government Information Quarterly, 29(1), 12-20. https://doi.org/10.1016/j.giq.2011.07.005

Nam, T. and Pardo, T. A. (2011). Smart city as urban innovation: Focusing onmanagement, policy, and context. Proceedings of the 5th International Conference on Theory and Practice of Electronic Governance, September 26-28, Tallinn, Estonia. https://doi.org/10.1145/2072069.2072100

Nam, T. and Pardo, T.A. (2014). The changing face of a city government: A case study of Philly311. Government Information Quarterly, 31, 1-9. https:/ / doi.org/10.1016/j.giq.2014.01.002

Neshkova, M. I. and Guo, H. D. (2012). Public participation and organizational performance: Evidence from state agencies. Journal of Public Administration Research and Theory, 22(2), $267-288$. https://doi.org/10.1093/jopart/mur038

O’Brien, D. T., Offenhuber, D., Baldwin-Philippi, J., Sands, M. and Gordon, E. (2017). Uncharted territoriality in coproduction: The motivations for 311 reporting. Journal of Public Administration Research and Theory, 27(2), 320335. https://doi.org/10.1093/jopart/muw046

O’Byrne, J. C. (2015). The Diffusion and Evolution of 311 Citizen Service Centers in American Cities from 1996 to $2012-A$ Study to Identify the Catalysts for the Adoption of Citizen Engagement Technology (Doctoral dissertation, Virginia Tech).

Offenhuber, D. (2014). Infrastructure legibility - a comparative analysis of open311-based citizen feedback systems. Cambridge Journal of Regions, Economy and Society, 8(1), 93-112. https://doi.org/10.1093/cjres/rsu001

Ramasubramanian, L. (2016). Using Geo-Spatial Knowledge for Good Governance. In Advancing Geographic Information Science: The Past and Next Twenty Years, 307-311. 
Schmidthuber, L., et al. (2017). The emergence of local open government: Determinants of citizen participation in online service reporting. Government Information Quarterly, 34(3), 457-469. https://doi.org/10.1016/j.giq.2017.07.001

Sheth, A. (2009). Citizen sensing, social signals, and enriching human experience. IEEE Internet Computing, 13(4), 87-92. https:// doi.org/10.1109/MIC.2009.77

Susanto, T. D., Diani, M. M. and Hafidz, I. (2017). User Acceptance of e-Government Citizen Report System (a Case Study of City113 App). Procedia Computer Science, 124, 560-568. https:// doi.org/10.1016/j.procs.2017.12.190

Swindell, D. and Kelly, J. M. (2000). Linking citizen satisfaction to performance measures: A preliminary evaluation. Public Performance and Management Review, 24(1), 30-52. https://doi.org/10.2307/3381075

Thompson, M. M. (2016). Upside-down GIS: The future of citizen science and community participation. The Cartographic Journal, 53(4), 326-334. https:// doi.org/10.1080/00087041.2016.1243863

Torres, L. H. (2007). Citizen sourcing in the public interest. Knowledge Management for Development Journal, 3(1), 134145.

Winkler, T. J. Ziekow, H. and Weinberg, M. (2012b). Municipal benefits of participatory Urban sensing: A simulation approach and case validation. Joumal of Theoretical and Applied Electronic Commerce Research, 7(3), 101120. https://doi.org/10.4067/S0718-18762012000300010

Winkler, T. J., Günther, O., Trouvilliez, G. and Hirsch, H (2012a). Participatory urban sensing: Citizens' acceptance of a mobile reporting service. Association for Information Systems, paper 106.

You, L., et al. (2016). CITY FEED: A Pilot System of Citizen-Sourcing for City Issue Management. ACM Transactions on Liget Systems and Technology, 7(4, SI), 53. https://doi.org/10.1145/2873064 